\title{
PENINGKATAN KOMPETENSI BISNIS ONLINE BAGI GURU MGMP BISNIS DARING DAN PEMASARAN DI SURABAYA
}

\author{
Septyan Budy Cahya'), Tri Sudarwanto'), Harti'1), Raya Sulistyowati'1), Veni Rafida') \\ 1)Jurusan Pendidikan Ekonomi, Fakultas Ekonomika dan Bisnis, Universitas Negeri Surabaya, Surabaya, Jawa Timur, \\ Indonesia \\ Corresponding author : Septyan Budy Cahya \\ E-mail : septyancahya@unesa.ac.id
}

Diterima 29 November 2021, Direvisi 02 Desember 2021, Disetujui 02 Desember 2021

\begin{abstract}
ABSTRAK
Kegiatan Pengabdian Kepada Masyarakat (PKM) ini bertujuan meningkatkan kompetensi dan skill guru-guru Musyawarah Guru Mata Pelajaran (MGMP) Jurusan Bisnis Daring dan Pemasaran di Surabaya dalam bidang bisnis online. Metode pelaksanaan kegiatan PKM yaitu melalui pelatihan dan pendampingan: a) Merancang strategi Bisnis Online b) merancang pembuatan website. c) merancang prosedur Pemasaran Online dengan menggunakan/ memanfaatkan e-mail dan Media Sosial. d) melakukan pemasaran melalui situs mobile. e) membuat Blog. Hasil Pelatihan yang dilaksanakan dirasa bermanfaat bagi mitra, dimana dari segi kompetensi pengetahuan yang didapat setelah kegiatan PKM, 86\% peserta memberikan respon sangat setuju, dan 14\% menjawab setuju. Para peserta mengharapkan adanya kegiatan seperti ini lagi, dimana ada kelanjutan kegiatan webinar atau pelatihan mengenai bisnis online. Akan tetapi dalam pelaksanaan selanjutnya peserta mengharapkan kegiatan untuk dilakukan secara luring atau offline sehingga kegiatan serupa bisa terlaksana lebih maksimal lagi.
\end{abstract}

Kata kunci: bisnis online; MGMP BDP kota Surabaya; pelatihan

\begin{abstract}
This Community Service activity aims to improve the competence and skills of MGMP teachers of the Online Business and Marketing Department in Surabaya in the field of online business. The method of implementing PKM activities is through training and mentoring: a) Designing Online Business strategies b) designing website creation. c) designing On-line Marketing procedures by using/utilizing e-mail and Social Media. d) conduct marketing through mobile sites. e) create a blog. The results of the training carried out were felt to be useful for partners, where in terms of knowledge competence obtained after PKM activities, $86 \%$ of participants responded strongly agree, and $14 \%$ answered agree. The participants hope that there will be more activities like this, where there will be a continuation of webinars or training on online business. However, in the next implementation, participants expect activities to be carried out offline or offline so that similar activities can be carried out more optimally.
\end{abstract}

Keywords: online business; MGMP BDP Surabaya city; training

\section{PENDAHULUAN}

Terdapat beberapa mata pelajaran baru dalam Kurikulum 2013 SMK untuk Program Keahlian Bisnis Daring dan Pemasaran sebagai penyesuaian terhadap dinamisasi kebutuhan dunia usaha dan dunia industri serta mengikuti perkembangan ilmu pengetahuan dan teknologi. Dalam muatan Kurikulum 2013 ini, untuk Jurusan Bisnis Daring dan Pemasaran, terdapat tiga sasaran yang dicapai, yaitu mendidik dan mempersiapkan siswa untuk: (1) menjadi profesi sebagai tenaga penjual pada perusahaan ritel baik sebagai pramuniaga ataupun kasir, (2) profesi sebagai tenaga penjual yang melayani penjualan langsung, dan (3) profesi sebagai pelaku dalam bisnis online.
Perkembangan bisnis saat ini dengan menggunakan internet mendorong siswa jurusan Bisnis Daring dan Pemasaran tidak hanya mempelajari pemasaran secara offline melainkan juga harus mempelajari pemasaran secara online. Penelitian oleh Erfianto dkk (2015:54) mengatakan bahwa "Siswa yang menggunakan teknologi dan sistem informasi dapat mendorong sikap dan perilaku untuk menjadi wirausahawan yang berbisnis secara online. Hasil penelitian Millman et.al (2010) disiplin ilmu dengan pengetahuan dan keterampilan terkait IT berpengaruh terhadap minat berwirausaha online siswa. Sehingga dimungkinkan pembelajaran pemasaran dengan menggunakan IT dapat meningkatkan minat siswa berwirausaha online. 
Bisnis Online merupakan mata pelajaran yang baru, baik dari sisi pengetahuan maupun dari sisi keterampilan. Para guru di bidang keahlian pemasaran selama ini banyak yang terbatas memiliki pengetahuan dan keterampilan pemasaran langsung (direct selling), sedangkan pengetahuan dan keterampilan bisnis online masih kurang. Melihat situasi dan kondisi ini, guru-guru MGMP Bisnis Daring dan Pemasaran Surabaya sebagai salah satu pemangku kepentingan berharap untuk adanya percepatan jumlah guru mata pelajaran Bisnis Online yang dapat mengikuti pelatihan bisnis online. Sebagai pilot project diharapkan MGMP Pemasaran Kota Surabaya dapat menyelenggarakan pelatihan Bisnis Online bagi seluruh guru di Kota Surabaya

Peningkatan kompetensi perlu dilakukan oleh setiap guru mata pelajaran Bisnis Online dalam rangka meningkatkan kualitas pembelajaran yang pada akhirnya menghasilkan siswa yang kompeten dalam bidang Bisnis Online. Untuk memfasilitasi kebutuhan guru pemasaran dalam peningkatan kompetensi khususnya mata pelajaran Bisnis Online, maka guru-guru MGMP Bisnis Daring dan Pemasaran Kota Surabaya memerlukan suatu pelatihan bisnis online.

Peningkatan kompetensi guru mata pelajaran Bisnis Online melalui pelatihan Bisnis Online diharapkan memberikan peningkatan pada aspek berikut: 1) Aspek pendidikan, pendidikan dan pelatihan jelas mempunyai nilai pendidikan, karena dengan meningkatnya pengetahuan dan keterampilan guru terhadap Bisnis Online, maka akan berdampak sangat positif terhadap meningkatnya keterampilan Bisnis Online pada siswa. Pendidikan dan pelatihan Bisnis Online dapat menghasilkan modul dan materi pembelajaran yang dapat digunakan sebagai kerangka acuan dalam menyusun bahan ajar yang dapat digunakan sebagai pegangan dalam melaksanakan proses pembelajaran praktik Bisnis Online di laboratorium. 2) Aspek kewirausahaan, peningkatan keterampilan guru pada akhirnya dapat meningkatkan keterampilan siswa dalam Bisnis Online, sehingga Bisnis Online dapat dijadikan sebagai salah satu keunggulan bagi institusi SMK dalam mendukung program pemerintah dalam penciptaan wirausaha muda dalam bidang technopreneur. Aspek psikologis, melalui pelatihan Bisnis Online akan meningkatkan sisi psikologis dalam hal kepercayaan diri guru dalam melaksanakan proses pembelajaran khususnya praktik Bisnis Online. 3) Aspek ekonomi, pelatihan Bisnis Online akan menjadikan guru Bisnis Online sebagai praktisi Bisnis Online, sehingga dapat menjadi salah satu sumber pendapatan dalam meningkatkan kondisi perekonomian guru.

\section{METODE}

Kegiatan PKM dilaksanakan pada tanggal 18 dan 21 Agustus 2021. melalui daring dengan menggunakan zoom meeting. Peserta pelatihan adalah guru MGMP BDP Kota Surabaya, dengan jumlah peserta sebanyak 35 guru.

Dalam Pelaksanaan kegiatan PKM Peningkatan Kompetensi Bisnis Online Bagi Guru MGMP Bisnis Daring Dan Pemasaran Di Surabaya dibagi menjadi 5 tahapan:

Tahap pertama, Persiapan dan koordinasi dengan Mitra. Dalam tahapan ini dilakukan pertemuan antara tim PKM dengan mitra membahas tentang permasalahan yang dihadapi mitra, solusi dari tim PKM, kebutuhan pelatihan dan Jadwal Pelaksanaan Pelatihan.

Tahap kedua, penyusunan modul pelatihan. Tim PKM melakukan pertemuan guna menyusun modul/handout sesuai dengan kebutuhan mitra.

Tahap ketiga, Pelatihan. Yaitu pelaksanaan kegiatan inti PKM dengan memberikan materi/pelatihan yang dilanjutkan dengan diskusi tanya jawab, dan pemberian tugas pada peserta pelatihan.

Tahap keempat, pendampingan dan review. Dalam tahap ini Pendampingan dilakukan oleh Tim PKM terkait perbaikan hasil pelatihan

Tahap kelima, evaluasi. Dimana dilakukan komunikasi dengan perwakilan mitra, dan penyebaran angket respon kepada seluruh peserta.

\section{HASIL DAN PEMBAHASAN}

Tahapan pertama, persiapan dan koordinasi dengan mitra

Pada tahap awal tim PKM melakukan koordinasi dengan mitra membahas tentang permasalahan yang dihadapi mitra, solusi dari tim PKM, kebutuhan pelatihan dan Jadwal Pelaksanaan Pelatihan. Solusi yang dapat ditawarkan untuk mengatasi permasalahanpermasalahan yang dialami oleh guru MGMP BDP Kota Surabaya adalah dengan mengadakan pelatihan Bisnis Online secara daring. Pada tahap ini juga telah disepakati jadwal pelaksanaan pelatihan, dimana kegiatan dilaksanakan selama 2 minggu dengan 2 hari pelaksanaan pemaparan materi melalui webmeeting dan selebihnya dilakukan reviuw tugas yang telah diberikan. 
Tahapan kedua, penyusunan materi pelatihan

Setelah diketahui kebutuhan dan jadwal pelaksanaan PKM, selanjutnya dilakukan Pertemuan tim PKM untuk Menyusun modul/handout sesuai dengan kebutuhan mitra. Dalam kegiatan ini koordinasi berhasil dilakukan dengan baik dan Tersusunnya modul/handout dalam bentuk Powerpoint untuk setiap materi yaitu materi tentang: 1) Strategi Bisnis Online, 2) Pemasaran Digital, 3) Implementasi Bisnis Online dengan menggunakan/ memanfaatkan Media Sosial, 4) Sosial Marketing IG dan FB, dan 5) Website Interaktif. Selain itu tim PKM juga sudah mulai menyebarkan pamphlet kegiatan yang telah dibuat seperti pada Gambar 1 berikut.

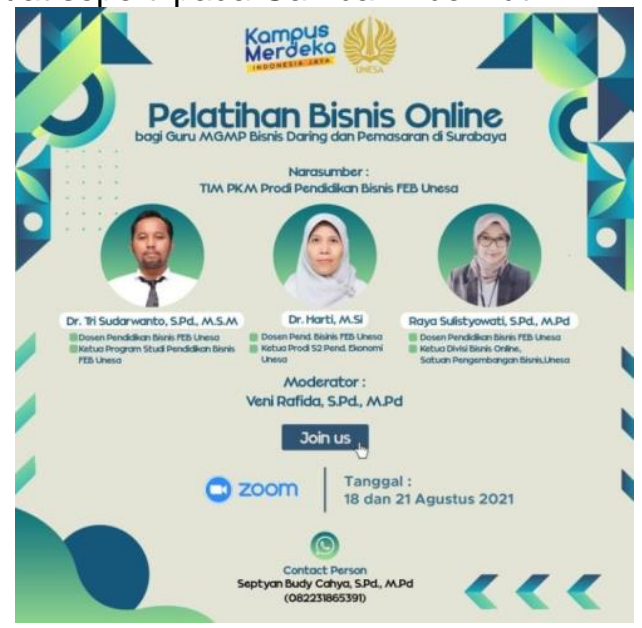

Gambar 1. Pamflet Kegiatan Pelatihan

\section{Tahap ketiga, pelatihan}

Tim PKM telah melaksanakan pelatihan secara online melalui media Zoom Meeting kepada guru MGMP BDP Kota Surabaya pada tanggal 18 dan 21 Agustus 2021. Pelatihan diikuti oleh 35 guru anggota MGMP BDP Kota Surabaya yang dapat dilihat pada Gambar 2, Gambar 3, dan Gambar 4.

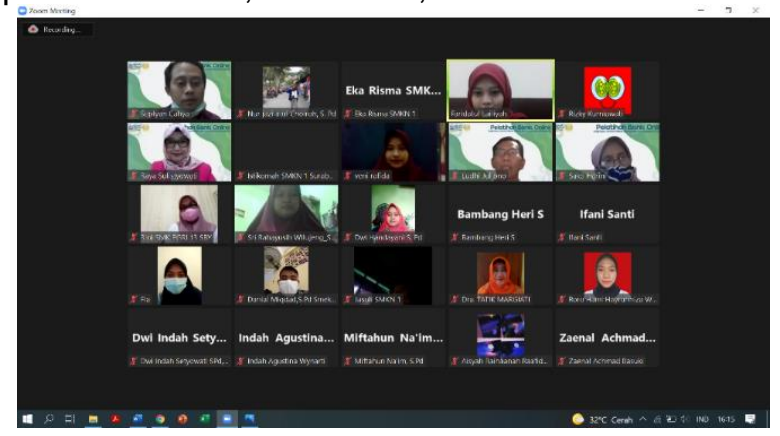

Gambar 2. Pelaksanaan Kegiatan Pelatihan

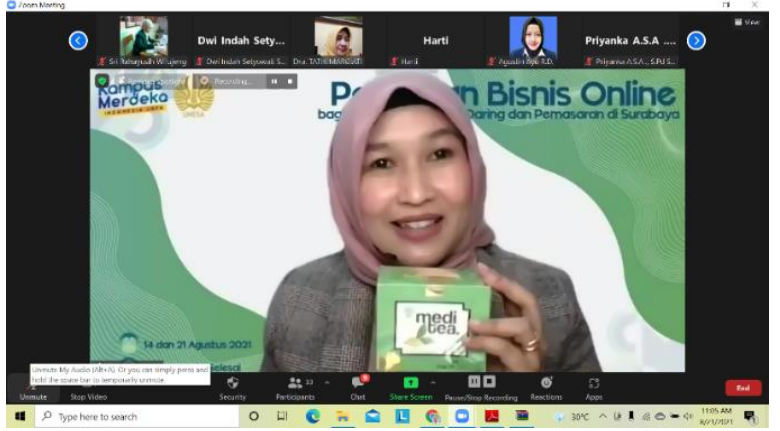

Gambar 3. Penyampaian Materi Tim PKM

Ada 5 materi yang diberikan oleh narasumber kepada peserta, yaitu materi 1) Strategi Bisnis Online, 2) Pemasaran Digital, 3) Implementasi Bisnis Online dengan menggunakan/ memanfaatkan Media Sosial, 4) Sosial Marketing IG dan FB, dan 5) Website Interaktif.

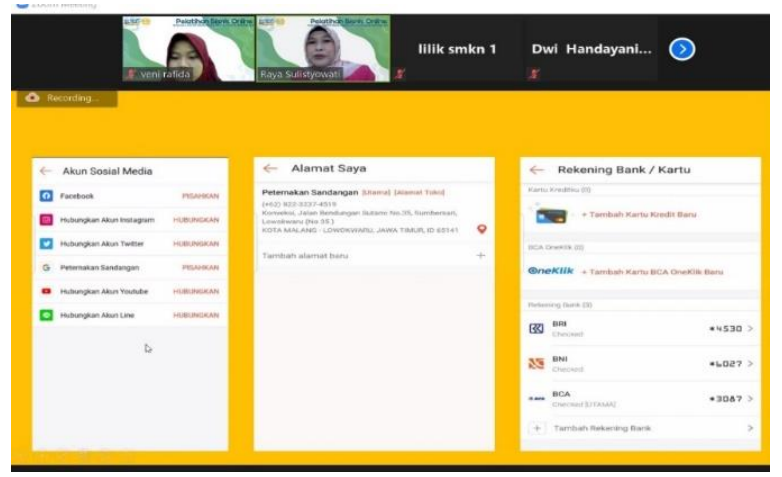

Gambar 4. Penyampaian Materi Tim PKM

Dalam pelaksanaan kegiatan tersebut berjalan dengan baik dan lancar sesuai dengan apa yang sudah direncanakan. Peserta dalam kegiatan juga mengikuti pelatihan dengan antusias dimana terdapat interaksi tanya jawab antara peserta dan pemateri.

\section{Tahapan keempat, Pendampingan dan Review Hasil \\ Pendampingan dilakukan oleh Tim} PKM terkait review dan perbaikan dari hasil tugas yang di kumpulkan oleh peserta. Adanya partisipasi peserta dalam pengerjaan dan pengumpulan tugas yang diberikan memperlancar kegiatan diskusi interaktif antara peserta dengan pendamping. Dimana kegiatan dilaksankan melalui daring menggunakan media Whatsapp Grup seperti gambar 5 dibawah ini. 


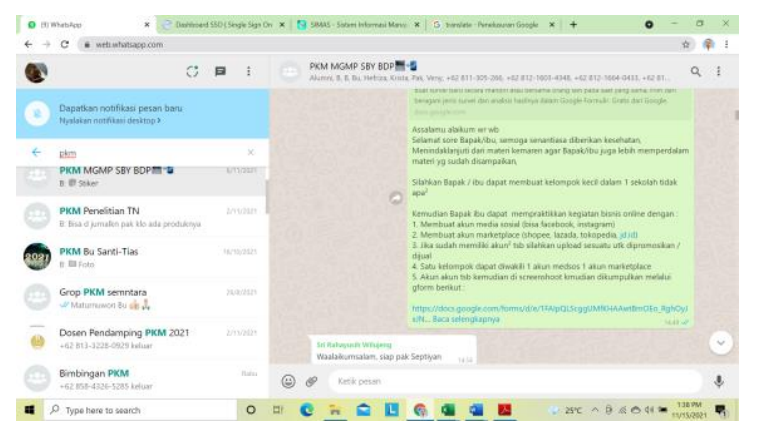

Gambar 5. Pelaksanaan Kegiatan Review dalam Pelatihan

\section{Tahapan kelima, evaluasi}

Tahapan terakhir dari kegiatan PKM ini adalah evaluasi, dari pelaksanaan secara keseluruhan berjalan dengan lancar. Dimana target peserta tercapai yaitu 35 peserta dari anggota guru MGMP BDP Kota Surabaya mengikuti pelatihan yang direncanakan. Dalam evaluasi ini Tim PKM memberikan angket respon kepada peserta melalui google form.

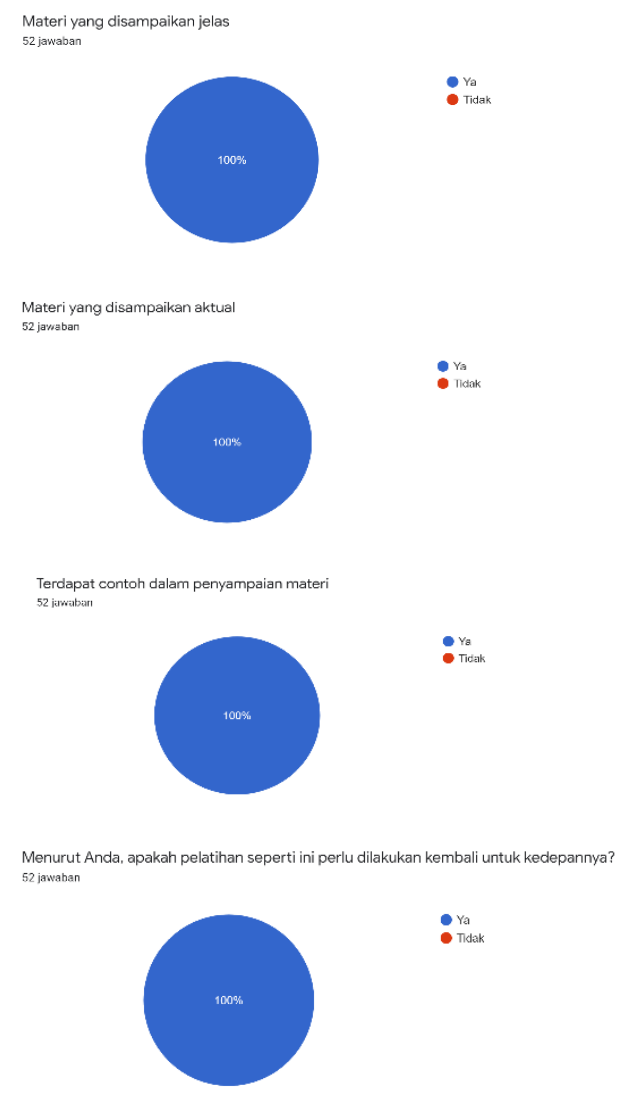

Gambar 6. Hasil Angket Respon Peserta

Dalam hasil rekap respon yang diambil, peserta menilai dalam kegiatan yang dilaksanakan yaitu, Materi yang disampaikan jelas, Materi yang disampaikan aktual, Terdapat contoh dalam penyampaian materi.
Kegiatan PKM yang dilaksanakan bermanfaat

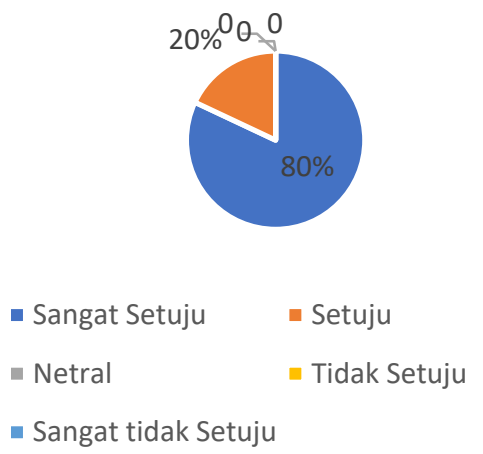

Gambar 7. Hasil Angket Respon Peserta

Selanjutnya secara manfaat para peserta juga memberikan tanggapan yang positif. Dari gambar diatas dapat kita lihat bahwa sebesar $80 \%$ peserta memberikan respon jawaban sangat setuju dan $20 \%$ setuju terhadap manfaat kegiatan PKM yang dilaksanakan.

\section{Pengetahuan saya tentang Bisnis Online bertambah setelah adanya kegiatan PKM

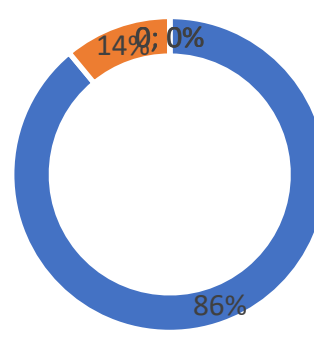 \\ - Sangat Setuju \\ - Setuju \\ - Netral \\ - Tidak Setuju}

Gambar 8. Hasil Angket Respon Peserta

Sedangkan untuk pengetahuan yang didapat setelah kegiatan PKM, 86\% peserta memberikan respon sangat setuju, dan $14 \%$ menjawab setuju. Para peserta mengharapkan adanya kegiatan seperti ini lagi, dimana ada kelanjutan kegiatan webinar atau pelatihan mengenai bisnis online. Akan tetapi dalam pelaksanaan selanjutnya peserta mengharapkan kegiatan untuk dilakukan secara luring atau offline sehingga kegiatan serupa bisa terlaksana lebih maksimal lagi.

\section{SIMPULAN DAN SARAN}

Kesimpulan dari kegiatan Pengabdian Kepada Masyarkat yang sudah dilaksanakan; Kegiatan PKM ini berjalan lancar sesuai dengan rencana karena mendapatkan dukungan dan antusias tinggi dari peserta. Meningkatnya pengetahuan dan pemahaman peserta pelatihan tentang bisnis online khususnya pembuatan website, social media, dan marketplace. Dan Meningkatnya 
kompetensi peserta dalam mengajarkan bisnis online secara baik, tepat, terarah, dan kekinian kepada siswa, sehingga dapat membekali siswa dengan pelajaran bisnis online.

Dari hasil evaluasi yang sudah dilakukan, diperoleh saran yaitu: Perlunya anggota MGMP Bisnis Daring dan Pemasaran kota Surabaya membiasakan menggunakan website dan aplikasi pemasaran online lainya dalam kesehariannya sehingga akan menambah pengetahuan dan pengalaman dalam proses belajar yang akan sangat membantu dalam mengajar peserta didiknya. Diadakan Kembali lanjutan dari kegiatan pelatihan dan workshop seperti ini, dan diselenggarakan secara periodik sehinga dapat meningkatkan kemampuan hardskill guru pembelajar dalam melaksanakan proses pembelajaran bisnis online. Pelatihan dilaksanakan secara offline atau luring sehingga pelaksanaan dapat berjalan dengan lebih maksimal.

\section{DAFTAR RUJUKAN}

Ahmadi, C \& Hermawan, D. (2013). E-Business \& E-Commerce. Yogyakarta: Penerbit Andi.

Amin, Fatkhul, (2015), Pemasaran Online Program Keahlian Tata Niaga untuk SMK/MAK, Penerbit Erlangga, Jakarta.

Anggraeni, Ari Andian. (2008). Manajemen Keyword: Strategi Pemasaran Online Menggunakan Search Engine .Jurnal Pendidikan Akuntansi Indonesia Vol. VI. No. 2 - Tahun 2008 Hal. 60 - 69.

Dianawati, A., (2008), "6 Rahasia Sukses Menjadi Jutawan Internet", Mediakita, Jakarta.

Erfianto, D., Rahayu, W. P., \& Kusumajanto,D. D. (2015). Penerapan Blog Sebagai Media Pembelajaran Mata Pelajaran Pemasaran Online. Jurnal Pendidikan Bisnis dan Manajemen, 1 (1), 1 - 70.

Kurnia, R.A., (2008), "Website yang Baik itu Memperindah Content, Bukan Desain!", (http://www.dibekasi.net/page_highlights. php?id_brt=55).

Millman, et al. (2010). Entrepreneurship Education and Students' Internet Entrepreneurship Intention. Journal of Small Business and Enterprise Development, 17 (4), 569- 590. Spiller \& Tuten. (2015). Integrating Metrics Across the Marketing Curriculum: The 